\title{
EFFECT OF $\mathrm{Sr}^{2+}$ DOPING ON THE STRUCTURAL, THERMAL, DIELECTRIC AND ELECTRICAL PROPERTIES OF $\mathrm{La}_{1-\mathrm{x}} \mathrm{Sr}_{\mathrm{x}} \mathrm{Co}_{0.50} \mathrm{Fe}_{0.50} \mathrm{O}_{3}\{0.1 \leq \mathrm{x} \leq 0.4\}$ CATHODE FOR SOFCS
}

\author{
Manokamna $^{1, \bowtie}$, Surinder Paul $^{1}$, A. Singh ${ }^{2}$, K. L. Singh ${ }^{3}$, G. Bhargava ${ }^{1}$ \\ and A. P. Singh ${ }^{1}$ \\ ${ }^{1}$ Department of Applied Sciences, IKGPT University, Kapurthala-144601(Punjab) India \\ ${ }^{2}$ Department of Physics, GNDU, Shri Amritsar-143006(Punjab) India \\ ${ }^{3}$ Department of Applied Sciences, DAV Institute of Engg. And Tech., \\ Jalandhar-144002(Punjab) India \\ ${ }^{\square}$ Corresponding Author: manokamna12333@gmail.com
}

\begin{abstract}
Solid solutions of perovskite $\mathrm{La}_{1-\mathrm{x}} \mathrm{Sr}_{\mathrm{x}} \mathrm{Co}_{0.50} \mathrm{Fe}_{0.50} \mathrm{O}_{3} ;\{0.1 \leq \mathrm{x} \leq 0.4\}$ ceramic material have been synthesized by solidstate route. Diffraction technique XRD has been used for structural analysis and results confirm single phase as well ascrystalline behavior of the perovskite. The morphology has been investigated by scanning electron microscopy which undoubtedly indicates a decrease of granule size by $\mathrm{Sr}^{2+}$ doping. Archimedes principle used to calculate the density which is observed to be decreasing with $\mathrm{Sr}^{2+}$ substitution and also isin good agreement with the microstructure. Thermogravimetric analyzer and dilatometer have been used to study the thermal properties which indicate a reduction of $\mathrm{Co} / \mathrm{Fe}$ near $600^{\circ} \mathrm{C}$ or above consequently generate the oxygen vacancies in the prepared material and thermal expansion coefficient value decreased with $\mathrm{Sr}$ substitution. The impedance, as well as dielectric properties, has been studied at dissimilar temperatures as well as the frequency which affirm the non-Debye relaxation nature of the prepared cathode perovskite. The electrical conductivity value has been investigated to be larger than $100 \mathrm{~S} / \mathrm{cm}$, which recommends it to be anappropriate material for the cathode of solid oxide fuel cells.
\end{abstract}

Keywords: Fuel Cell, Perovskite, Cathode, XRD, TEC, Dielectric Constant

RASĀYAN J. Chem., Vol. 14, No.2, 2021

\section{INTRODUCTION}

The exhausts of fossil fuel sources make it a necessity to locate clean and feasible alternative energy sources. Solid oxide fuel cell (SOFC) is a striking optional energy source due to its reasonable inexpensiveness and elevated efficiency. ${ }^{1-4}$ Material fabricates SOFCs play a very important role to achieve such high efficiency and therefore, in the procession of such material perovskite proved its role as a significant cathode material of SOFCs. ${ }^{5}$ However, few issues limit the usefulness of these materials which include electrochemical performance as its electrical conductivity decreased with temperature reduction and nonequality of thermal expansion coefficient with the electrolyte.$^{6-7}$ The introduction of element $\mathrm{P}$ can considerably decrease the resistance of polarization toward ORR ${ }^{8-9}$ Magnetic insulators $\mathrm{LaFeO}_{3}$ have antiferromagnetic ordering and with appropriate ion substitution, it is suggested to be the cathode of SOFCs. ${ }^{10}$ In lanthanum ferrite $\left(\mathrm{LaFeO}_{3}\right), \mathrm{Fe}^{3+}$ ion has $3 \mathrm{~d}^{5}$ stable electronic configuration and $\mathrm{Sr}$ substituted $\mathrm{LaFeO}_{3}$ cathodes show hopeful performance regarding the stability and power density at $750^{\circ} \mathrm{C} .{ }^{11-13}$ Due to excellent oxygen diffusivity, $\mathrm{La}_{1-\mathrm{x}} \mathrm{Sr}_{\mathrm{x}} \mathrm{CoO}_{3-\delta}$ has a striking electrode activity and shows marked dissociation ability towards $\mathrm{O}_{2}$ molecules. ${ }^{14} \mathrm{But}$ due to the large quantity of Coincrease the coefficient of thermal expansion (TEC) and consequence may be crack in the electrolyte ordel aminating the cathode/electrolyte interface. ${ }^{15}$ To eliminate these issues we decided to substitute $\mathrm{Sr}^{2+}$ at $\mathrm{A}$ siteusing varying content to form the charge inequity and consequently increase conductivity. Another approach is to balance the unequal charge by the creation of $\mathrm{O}_{2}$ vacancies on substitution of $\mathrm{Co}$ at $\mathrm{B}$ side with fixed concentration. Therefore in the present work $\mathrm{La}_{1-\mathrm{x}} \mathrm{Sr}_{\mathrm{x}} \mathrm{Co}_{0.50} \mathrm{Fe}_{0.50} \mathrm{O}_{3}(0.1 \leq \mathrm{x} \leq 0.4)$, solid solutions have been prepared by solid-state process and samples are characterized for thermal, structural, dielectric as well as electrical measurements. 
RASĀYAN J. Chem.

Vol. 14 | No. 2 |1019-1027| April - June | 2021

\section{EXPERIMENTAL}

Bulk material of $\mathrm{La}_{1-\mathrm{x}} \mathrm{Sr}_{\mathrm{x}} \mathrm{Co}_{0.50} \mathrm{Fe}_{0.50} \mathrm{O}_{3}$, where $x$ varies from 0.1 to 0.4 was prepared by the solid-state method. Raw powders of $\mathrm{SrCO}_{3}, \mathrm{La}_{2} \mathrm{O}_{3}, \mathrm{CoO}$ and $\mathrm{Fe}_{2} \mathrm{O}_{3}$ (pure $99.9 \%$, Sigma Aldrich) were used in a stoichiometric ratio to prepare the samples. The mixed powders were milled for 6 hours by using balls of zirconia oxide and acetone as solvent. Ball milled powder was mixed further thoroughly by using pestle and agate mortar for 2 hours in wet medium and then sieved using a 70-mesh sieve. Ground prepared powder was then exposed to calcination conventionally at $1200^{\circ} \mathrm{C}$ temperature for twelve hours. Obtained calcined powder was further mixed with $2 \mathrm{wt} \%$ PVA used for proper binding. Pellets of $1 \mathrm{~mm}$ thickness and $10 \mathrm{~mm}$ diameter were prepared. Prepared pellets were further sinter conventionally at 1400degree temperature for two hours for proper grain growth and densification of the samples.

\section{Structural Analysis and Physical Properties}

\section{RESULTS AND DISCUSSION}

X-ray powder diffraction (XRD) of the samples was carried out by x-ray diffractometer from Shimadzu Maxima 7000 (Japan) at room temperature. X-rays of wavelength $(\lambda) 1.54 \AA$ were used to obtain the diffraction pattern with a 0.02 degree step size, range $20^{\circ}$ to $80^{\circ}$ and speed of two degrees/minute. XRD patterns are given away in Fig.-1. The elevated intensity and pointed crystalline peaks recognized that the prepared samples were well crystallized. X'Pert High Score Plus software was used to analyze the XRD data. All the peaks present in XRD patterns were indexed according to crystal structure cubic, $\mathrm{Pm}-3 \mathrm{~m}$ space group and its number is 221 . In the XRD pattern, no one crystalline peak left unidentified which recognized that the solid solution was very fine crystallized in the solo phase. The different parameter belongs to crystallography are showing in Table-1.

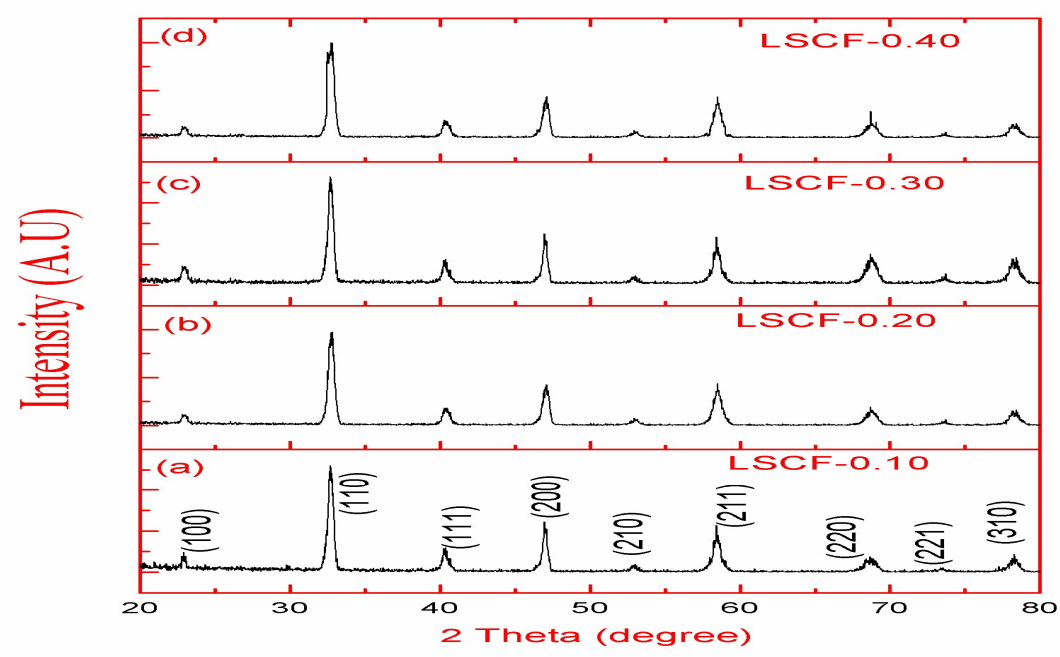

Fig.-1: XRD Patterns of $\mathrm{La}_{1-\mathrm{x}} \mathrm{Sr}_{\mathrm{x}} \mathrm{Co}_{0.50} \mathrm{Fe}_{0.50} \mathrm{O}_{3}(0.1 \leq \mathrm{x} \leq 0.4)$ Perovskites

Table1: Crystallographic Parameters of $\mathrm{La}_{1-\mathrm{x}} \mathrm{Sr}_{\mathrm{x}} \mathrm{Co}_{0.50} \mathrm{Fe}_{0.50} \mathrm{O}_{3}(0.1 \leq \mathrm{x} \leq 0.4)$ Perovskites

\begin{tabular}{c|c|c|c|c}
\hline \multirow{2}{*}{ Composition } & Lattice Parameters & $\begin{array}{c}\text { Cell Volume } \\
\mathrm{V}\left(\AA^{3}\right)\end{array}$ & $\begin{array}{c}\text { Volume } \\
\text { (Occupied) }\end{array}$ & $\begin{array}{c}\text { Volume } \\
\text { (Specific Free) }\end{array}$ \\
\cline { 2 - 3 } & $\mathrm{a}=\mathrm{b}=\mathrm{c}(\AA)$ & 58.411 & 40.531 & 0.30611 \\
\hline $\mathrm{La}_{0.90} \mathrm{Sr}_{0.10} \mathrm{Co}_{0.50} \mathrm{Fe}_{0.50} \mathrm{O}_{3}$ & 3.88 & 56.181 & 40.759 & 0.27451 \\
\hline $\mathrm{La}_{0.80} \mathrm{Sr}_{0.20} \mathrm{Co}_{0.50} \mathrm{Fe}_{0.50} \mathrm{O}_{3}$ & 3.83 & 54.010 & 40.987 & 0.24112 \\
\hline $\mathrm{La}_{0.70} \mathrm{Sr}_{0.30} \mathrm{Co}_{0.50} \mathrm{Fe}_{0.50} \mathrm{O}_{3}$ & 3.78 & 54.439 & 41.215 & 0.24291 \\
\hline $\mathrm{La}_{0.60} \mathrm{Sr}_{0.40} \mathrm{Co}_{0.50} \mathrm{Fe}_{0.50} \mathrm{O}_{3}$ & 3.79 & &
\end{tabular}

\section{Microstructure}

A scanning electron microscope was used to determine the surface morphology as well as the average grain size of the prepared perovskite samples. The SEM micrographs of prepared solid solutions are shown in Fig.-2. The grains are very well attached because of the good sintering of the material. The grains are 
RASĀYAN J. Chem.

Vol. 14 | No. 2 |1019-1027| April - June | 2021

randomly oriented, non-uniform and the size of the grains is observed to be decreasing with Sr doping at the A- site of perovskite samples. Values of average grain size are given in Table-2.
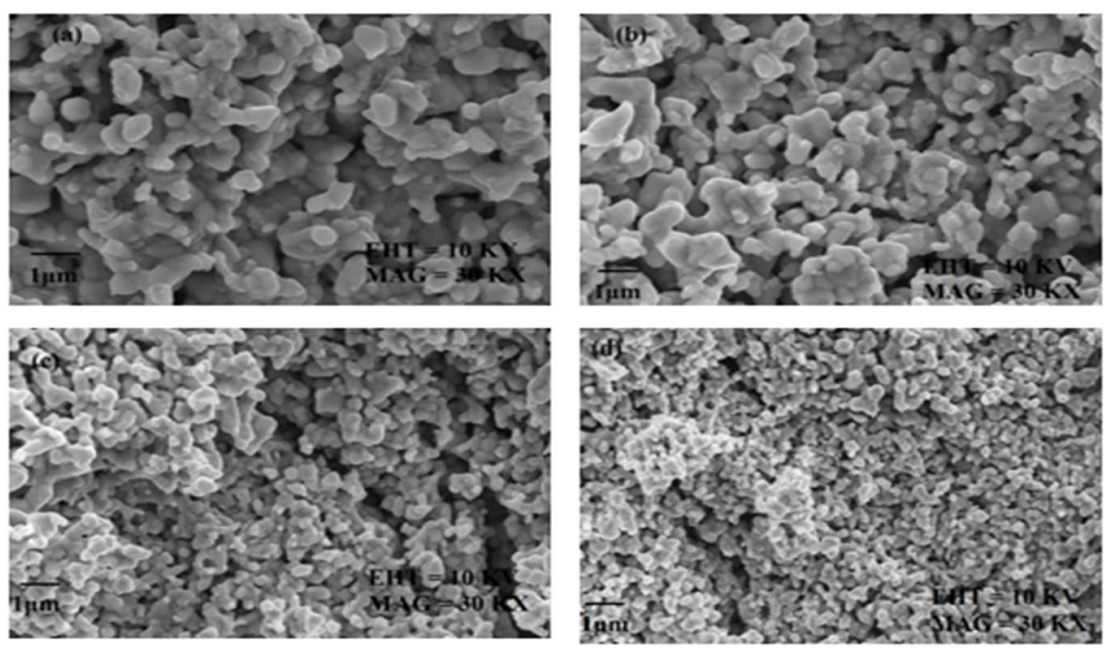

Fig.-2: Micrographs of $\mathrm{La}_{1-\mathrm{x}} \mathrm{Sr}_{\mathrm{x}} \mathrm{Co}_{0.50} \mathrm{Fe}_{0.50} \mathrm{O}_{3}(0.1 \leq \mathrm{x} \leq 0.4)$ Solid Solutions

\section{Density}

Archimede's method was used to determine the density (experimental) of the material. Density (theoretical) was obtained by using the following equation:

$$
\rho=\frac{W_{a}}{W_{a}-W_{l}} \times \rho_{\text {liquid }}
$$

Where $W_{l}$ and $W_{a}$ are the weight of prepared pellets in fluid and air respectively. $\rho$ and $\rho_{\text {liquid }}$ is the density of prepared pellet and density of the used fluid respectively. The density of the material lowered with the increasing Sr concentration in the material. Density, grain size, and tolerance factor are given in Table-2.

Table-2: Calculated Density, MeanGrainSizeas well asTolerance Factor of $\mathrm{La}_{1-\mathrm{x}} \mathrm{Sr}_{\mathrm{x}} \mathrm{Co}_{0.50} \mathrm{Fe}_{0.50} \mathrm{O}_{3}(0.1 \leq \mathrm{x} \leq 0.4)$.

\begin{tabular}{|c|c|c|c|c|c|c|}
\hline \multirow[t]{2}{*}{ Samples } & \multicolumn{3}{|c|}{ Density } & \multirow{2}{*}{$\begin{array}{c}\text { MeanSiz } \\
\text { e of } \\
\text { Grain } \\
(\mu \mathrm{m})\end{array}$} & \multirow{2}{*}{$\begin{array}{l}\text { Deviation } \\
\text { (size) }\end{array}$} & \multirow{2}{*}{$\begin{array}{l}\text { Tolerance } \\
\text { factor }\end{array}$} \\
\hline & $\begin{array}{c}\text { Density } \\
\left(\mathrm{d}_{\text {Theoretical }}\right) \\
\left(\mathrm{g} \mathrm{cm}^{-3}\right) \\
\end{array}$ & $\begin{array}{c}\text { Density } \\
\left(\mathrm{d}_{\text {Experimental }}\right) \\
\left(\mathrm{g} \mathrm{cm}^{-3}\right)\end{array}$ & $\begin{array}{c}\mathrm{d}_{\text {Experimental }} \\
\left./ \mathrm{d}_{\text {Theoretical }}\right] \\
(\%)\end{array}$ & & & \\
\hline $\mathrm{La}_{0.90} \mathrm{Sr}_{0.10} \mathrm{Co}_{0.50} \mathrm{Fe}_{0.50} \mathrm{O}_{3}$ & 5.8782 & 5.683 & 96.679 & 0.54 & 0.24 & 0.730 \\
\hline $\mathrm{La}_{0.80} \mathrm{Sr}_{0.20} \mathrm{Co}_{0.50} \mathrm{Fe}_{0.50} \mathrm{O}_{3}$ & 5.71997 & 5.646 & 98.706 & 0.50 & 0.26 & 0.731 \\
\hline $\mathrm{La}_{0.70} \mathrm{Sr}_{0.30} \mathrm{Co}_{0.50} \mathrm{Fe}_{0.50} \mathrm{O}_{3}$ & 5.56351 & 5.544 & 99.649 & 0.24 & 0.21 & 0.732 \\
\hline $\mathrm{La}_{0.60} \mathrm{Sr}_{0.40} \mathrm{Co}_{0.50} \mathrm{Fe}_{0.50} \mathrm{O}_{3}$ & 5.40878 & 5.335 & 98.635 & 0.19 & 0.16 & 0.732 \\
\hline
\end{tabular}

\section{Thermo-gravimetric Analysis}

The thermo-gravimetric analysis (TGA) of the sintered pellet was obtained in an air atmosphere at a heating rate $5{ }^{\circ} \mathrm{C}$ per minute with a temperature range of $50{ }^{\circ} \mathrm{C}$ to $800{ }^{\circ} \mathrm{C}$ with $\mathrm{Al}_{2} \mathrm{O}_{3}$ powder were used as reference material. Thermogravimetric analysis curves of $\mathrm{La}_{1-\mathrm{x}} \mathrm{Sr}_{\mathrm{x}} \mathrm{Co}_{0.50} \mathrm{Fe}_{0.50} \mathrm{O}_{3}$ ceramic for $\mathrm{x}=0.1$ and 0.4are shown in Fig.-3. TGA curves initially show sharp weight loss up to temperature $200^{\circ} \mathrm{C}-300{ }^{\circ} \mathrm{C}$.

This weight loss may occur due to loss of the moisture present in samples as well as carbonate change into oxides. Above $300{ }^{\circ} \mathrm{C}$ the weight change is comparably small. In the perovskite material creation of oxygen vacancies at high temperatures may be the reason for weight loss. Weight change rose because of charge imbalance occurs in the prepared material on $\mathrm{Sr}^{2+}$ substitution at $\mathrm{A}$-site which is compensated by a reduction of $\mathrm{Co} / \mathrm{Fe}$ substituted at $\mathrm{B}$-site of the $\mathrm{LaFeO}_{3}$ perovskite material. ${ }^{16,17}$

\section{Thermal Expansion Coefficient}

Mismatching of TEC with another component of the cell gives rise to thermal stresses and reduces cell performance. $\Delta \mathrm{L} / \mathrm{L}_{0}$ versus temperature curves for all the compositions of prepared materials up to 
RASĀYAN J. Chem.

Vol. 14 | No. 2 |1019-1027| April - June | 2021

temperature $800{ }^{\circ} \mathrm{C}$ are shown in given Fig.-4. The calculated value of TEC of $\mathrm{La}_{1-x} \mathrm{Sr}_{\mathrm{x}} \mathrm{Co}_{0.50} \mathrm{Fe}_{0.50} \mathrm{O}_{3}$ for $\mathrm{x}$ belongs to 0.1 and 0.4 at temperatures 200 degrees and 800 degrees is $15.4 \times 10^{-6}$ and $13.7 \times 10^{-6}$ per degree Celsius respectively. The main cause of lowering or raising TEC is gain or loss of lattice oxygen of the oxides at high value of temperature and also the existence of superstructure in addition to the ordering of $\mathrm{O}_{2}$ vacancies may be the cause of change in TEC because potential energy well becomes more symmetric with the high-quality ordering of oxygen vacancies. ${ }^{17-18}$ In prepared material with $\mathrm{Sr}$ doping the TEC, value is decreased which shows that reduction of Co takes place at a high value of temperature which gives rise to the formation of $\mathrm{O}_{2}$ vacancies in the solid because of larger radii (ionic) of $\mathrm{Co}^{3+}$ as compare to $\mathrm{Co}^{4+}$.

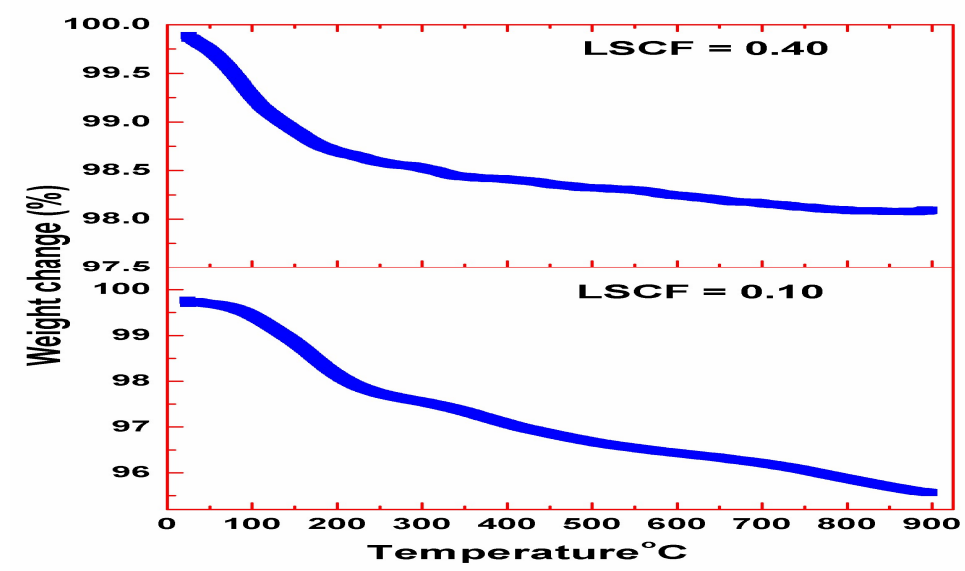

Fig.-3: TGA Curves of $\mathrm{La}_{1-\mathrm{x}} \mathrm{Sr}_{\mathrm{x}} \mathrm{Co}_{0.50} \mathrm{Fe}_{0.50} \mathrm{O}_{3}(\mathrm{x}=0.1$ and 0.4$)$ Solid Solutions
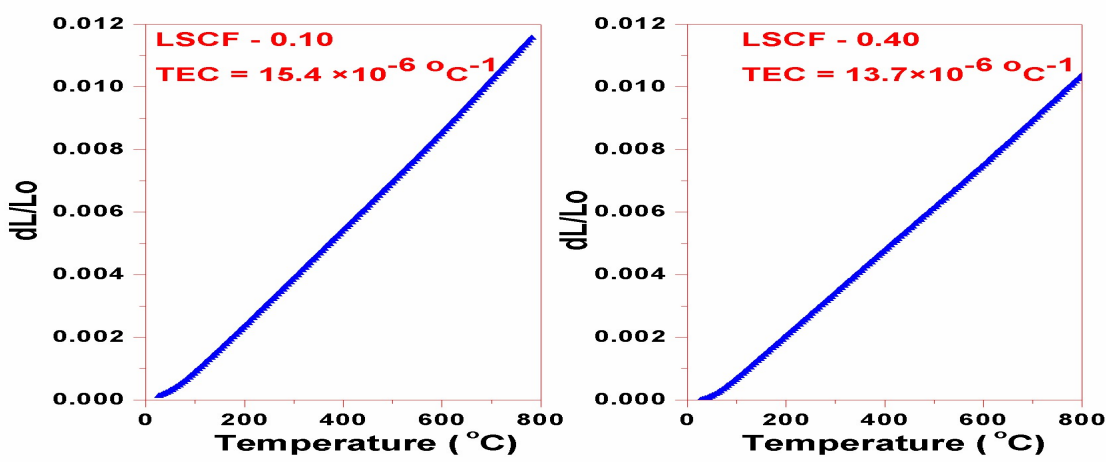

Fig.-4: Thermal Expansion Curves of $\mathrm{La}_{1-\mathrm{x}} \mathrm{Sr}_{\mathrm{x}} \mathrm{Co}_{0.50} \mathrm{Fe}_{0.50} \mathrm{O}_{3}(\mathrm{x}=0.1$ and 0.4$)$ Solid Solutions

\section{Dielectric Properties}

Relative dielectric permittivity is the function of frequency, expressed by the subsequent relation:

$$
\varepsilon_{\mathrm{r}}[\omega]=\varepsilon^{\prime}[\omega]-\mathrm{i} \omega \varepsilon^{\prime \prime}[\omega]
$$

Where $\varepsilon^{\prime}[\omega]$ be dielectric constant (real component) which is in phase using field applied and $\varepsilon^{\prime \prime}[\omega]$ be the imaginary component of dielectric constant which is in quadrature using field applied. $\varepsilon_{\mathrm{r}}=\varepsilon / \varepsilon_{0} .\left(\varepsilon_{0}\right.$ is the dielectric permittivity in free space) furthermore, $\omega$ be angular frequency. The temperature-based $\varepsilon^{\prime}$, as well as $\varepsilon^{\prime \prime}$ with respect to frequency of applied field at dissimilar temperature values, are shown in Fig.5 as well asFig.-6, respectively. Both $\varepsilon^{\prime}$, as well as $\varepsilon^{\prime \prime}$ curves, are fitted using the Cole-Cole model given below which represents a relaxation model inured to express dielectric relaxations. ${ }^{19}$ Exponent $\alpha$, be a parameter that is inured to depict varied spectral shapes. When $\alpha=0$, the Cole-Cole model represents Debye behavior and confers stretched relaxation. On the other hand $\alpha>0$, signifying that systems moving towards non-Debye nature. Table- 3 indicates that the exponents, all $\alpha$-values above zero signifying the non-Debye relaxation nature of the system. 
RASĀYAN J. Chem.

Vol. 14 | No. 2 |1019-1027| April - June | 2021

$$
\begin{gathered}
\varepsilon^{\prime}=\varepsilon_{\infty}+\frac{\left(1+\sin \frac{\alpha \pi}{2}(\omega \tau)^{(1-\alpha)}\right)\left(\varepsilon_{0}-\varepsilon_{\infty}\right)}{\left(1+(\omega \tau)^{2(1-\alpha)}+2 \sin \frac{\alpha \pi}{2}(\omega \tau)^{(1-\alpha)}\right)} \\
\varepsilon^{\prime \prime}=\frac{\left.(\omega \tau)^{(1-\alpha)} \cos \frac{\alpha \pi}{2}\right)\left(\varepsilon_{0}-\varepsilon_{\infty}\right)}{\left(1+(\omega \tau)^{2(1-\alpha)}+2 \sin \frac{\alpha \pi}{2}(\omega \tau)^{(1-\alpha)}\right)}
\end{gathered}
$$

In the lower region of frequency both $\varepsilon^{\prime}$ (real)and $\varepsilon^{\prime \prime}$ (imaginary) incessantly decrease concerning frequency by the side of all value of temperature and nearly show a linear behavior in the area of elevated frequency. This kind of behavior is incredibly well described by the dipolar relaxation phenomenon. ${ }^{20}$ In the lower frequency region, all forms of the polarizations ionic, electronic, dipolar and space charge contribute their role and result in the highest polarizability. In the area of elevated frequency both $\varepsilon^{\prime}$ in addition to $\varepsilon^{\prime \prime}$ drop back the switching signal of orientation like dipolar, which further consequences around linear variation in that region because of filter out few polarizations among the overall polarizability. This variation perhaps rose due to polarization like interfacial and does not belong to polarization like dipolar.
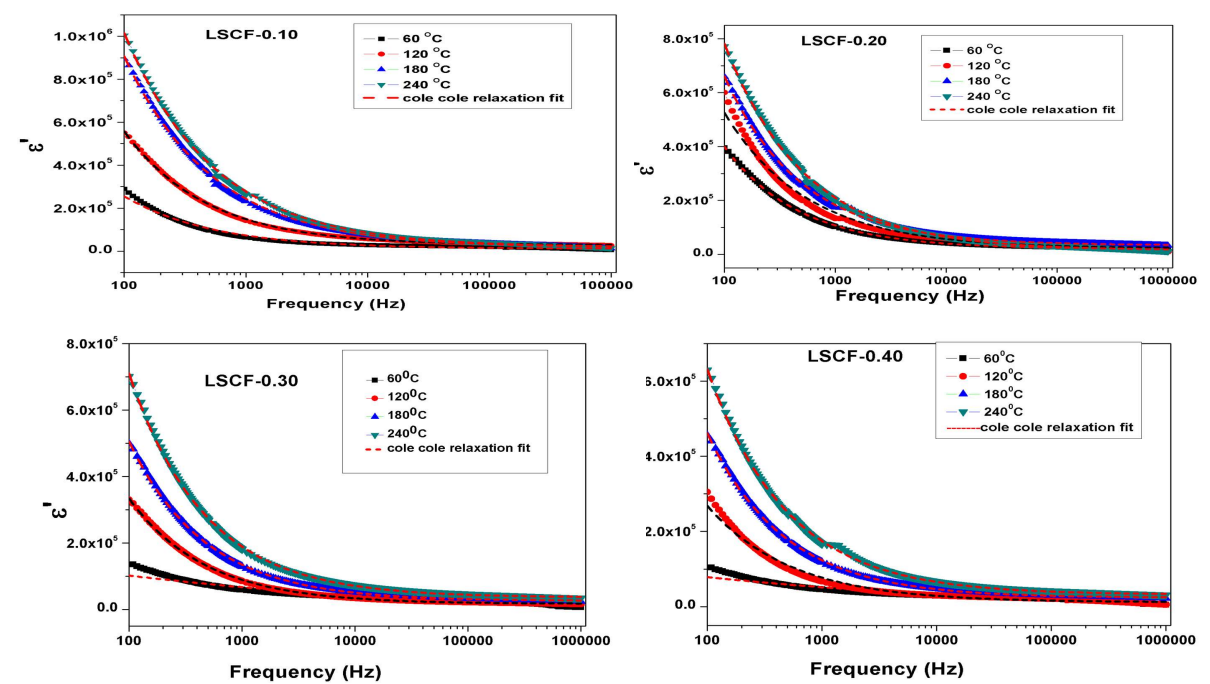

Fig.-5: Variation of Real Component $\varepsilon^{\prime}$ Concerning Frequency of $\mathrm{La}_{1-\mathrm{x}} \mathrm{Sr}_{\mathrm{x}} \mathrm{Co}_{0.50} \mathrm{Fe}_{0.50} \mathrm{O}_{3}(0.1 \leq \mathrm{x} \leq$

0.4) Perovskite
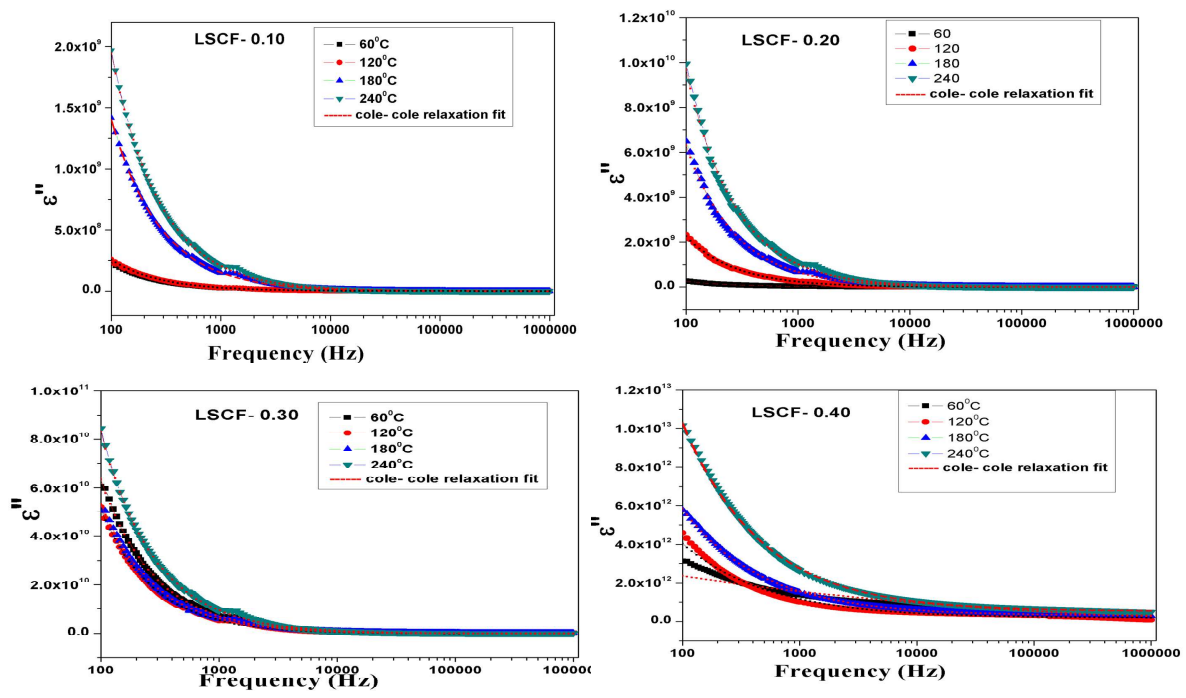

Fig.-6: Variation of Imaginary Component $\varepsilon^{\prime \prime}$ with respect to Frequency of $\mathrm{La}_{1-\mathrm{x}} \mathrm{Sr}_{\mathrm{x}} \mathrm{Co}_{0.50} \mathrm{Fe}_{0.50} \mathrm{O}_{3}(0.1 \leq \mathrm{x} \leq 0.4)$ Perovskite

1023 
RASĀYAN J. Chem.

Vol. 14 | No. 2 |1019-1027| April - June | 2021

Table-3: $\alpha$-Parameter Values at Dissimilar Temperature of $\mathrm{La}_{1-\mathrm{x}} \mathrm{Sr}_{\mathrm{x}} \mathrm{Co}_{0.50} \mathrm{Fe}_{0.50} \mathrm{O}_{3}(0.1 \leq \mathrm{x} \leq 0.4)$ Perovskite

\begin{tabular}{c|c|c|c|c|c|c|c|c}
\hline \multirow{2}{*}{$\begin{array}{c}\text { Temperature } \\
\left({ }^{\circ} \mathrm{C}\right)\end{array}$} & \multicolumn{2}{|c|}{ LSCF- 0.10} & \multicolumn{2}{c|}{ LSCF- 0.20} & \multicolumn{2}{c}{ LSCF- 0.30} & \multicolumn{2}{c}{ LSCF- 0.40} \\
\cline { 2 - 8 } & $\varepsilon^{\prime}$ & $\varepsilon^{\prime \prime}$ & $\varepsilon^{\prime}$ & $\varepsilon^{\prime \prime}$ & $\varepsilon^{\prime}$ & $\varepsilon^{\prime \prime}$ & $\varepsilon^{\prime}$ & $\varepsilon^{\prime \prime}$ \\
\hline 60 & 0.412 & 0.034 & 0.391 & 0.042 & 0.417 & 0.045 & 0.451 & 0.083 \\
\hline 120 & 0.365 & 0.028 & 0.423 & 0.012 & 0.366 & 0.024 & 0.348 & 0.097 \\
\hline 180 & 0.85 & 0.013 & 0.384 & 0.094 & 0.384 & 0.016 & 0.376 & 0.084 \\
\hline 240 & 0.846 & 0.035 & 0.412 & 0.101 & 0.348 & 0.023 & 0.643 & 0.091 \\
\hline
\end{tabular}

\section{Impedance Spectroscopy}

The real component $Z^{\prime}$, as well as imaginary component $Z^{\prime \prime}$ of impedance w.r.t. frequency for $\mathrm{x}=0.10$ and 0.40 samples in temperature range $60 \mathrm{oC}$ to $240 \mathrm{oC}$, is shown in Fig. -7 . From the graph, it is revolved that $\mathrm{Z}^{\prime}$ has a large value at the lesser value of temperature moreover also with increasing frequency, its magnitude decreases which confirm that the prepared material show typical negative temperature coefficient of resistance. $^{21}$
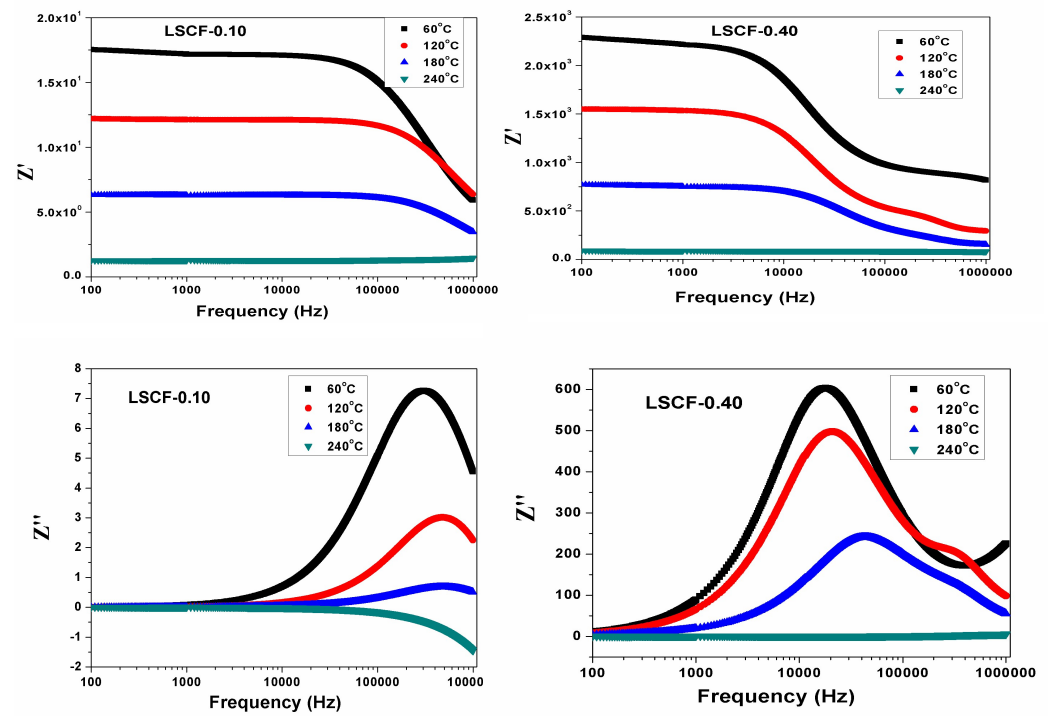

Fig.-7: Variation of $Z^{\prime}$ (real) and $Z^{\prime \prime}$ (Imaginary) VsFrequencyLa $\mathrm{La}_{1-\mathrm{x}} \mathrm{Sr}_{\mathrm{x}} \mathrm{Co}_{0.50} \mathrm{Fe}_{0.50} \mathrm{O}_{3}(\mathrm{x}=0.1$ and 0.4) Perovskite

Therefore, decreasing the value of $Z^{\prime}$ with increasing both frequency and temperature indicates enhancement of electrical conductivity. ${ }^{22,23} Z^{\prime}$ merges ina region of high frequency show that material has a reduction of barrier properties. ${ }^{24,25}$ The decreasing character of $Z$ " with enhancing both frequency and temperature confirm the fall of the resistive natureof the material. Peaks broadeningon increasing the temperature revolves that the prepared samples show temperature based electrical relaxation occurrence and in the region,soaring frequency, merging of $Z^{\prime \prime}$ curves indicate the disappearance of polarization raised doe tospace charge. ${ }^{26,27}$

\section{Electrical Properties}

The conductivity of the prepared samples has been calculated using formula $\mathrm{G}\left(\frac{l}{A}\right)=\sigma a c$, where $\mathrm{G}$ be the conductance, $\sigma a c$ be the ac conductivity, 1 be thickness and A be the cross-sectional area of the pellets. Electrical conductivity variation relating to temperature at dissimilar frequencies from $25^{\circ} \mathrm{C}$ temperature to $600^{\circ} \mathrm{C}$ temperature ofLa ${ }_{1-x} \mathrm{Sr}_{x} \mathrm{Co}_{0.50} \mathrm{Fe}_{0.50} \mathrm{O}_{3}(\mathrm{x}=0.1$ and 0.4$)$ samples is exposed in Fig.-8. It is undoubtedly found from the graph that with enhance in temperature as well as frequency conductivity continuously increases. The maximum value of the conductivity is $156.44 \mathrm{~S} / \mathrm{cm}$ as well as $189.80 \mathrm{~S} / \mathrm{cm}$ for $\mathrm{x}=0.1$ and 0.4 respectively, which also shows that the Sr modification increases the conductivity.

At a high value of temperature, $\mathrm{Co}^{3+} / \mathrm{Fe}^{4+}$ ions reduce to $\mathrm{Co}^{2+} /\left(\mathrm{Fe}^{2+} / \mathrm{Fe}^{3+}\right)$ ions and result in the generation of oxygen vacancies in the materials. As the $\mathrm{Sr}$ doping has been enhanced in the material, there may be the extra probability of reduction of ions and creation of $\mathrm{O}_{2}$ vacancies in the prepared 
RASĀYAN J. Chem.

Vol. 14 | No. 2 |1019-1027| April - June | 2021

material which future becomes the cause of raising the conductivity of the material. Grain size, grain boundaries and defects of the material play an especially important part in the conductivity of the material.
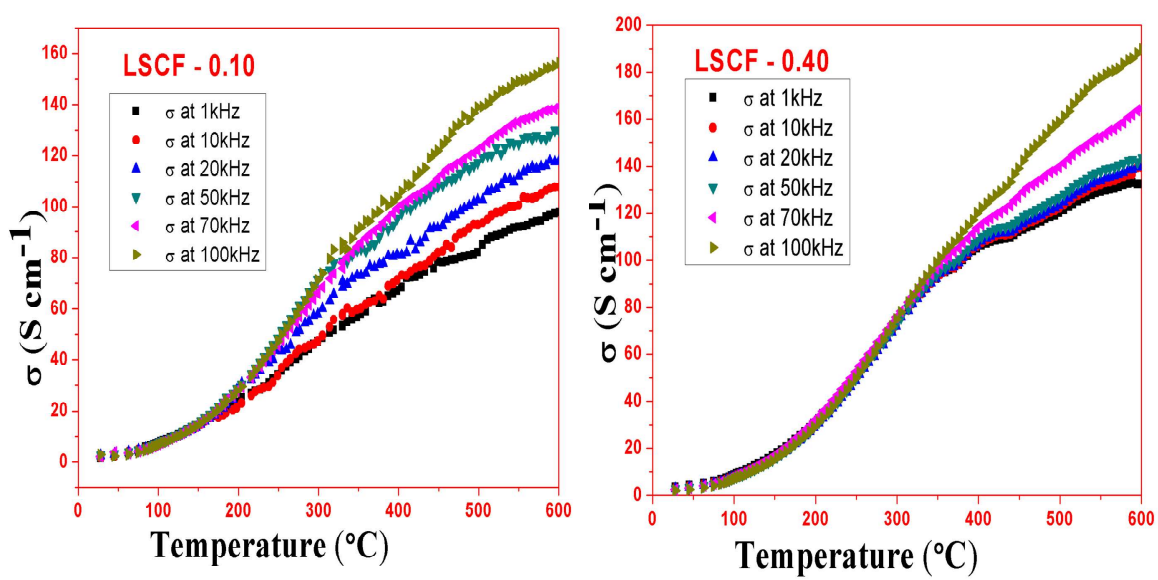

Fig.-8: Variation of Conductivity with respect to Temperature of $\mathrm{La}_{1-\mathrm{x}} \mathrm{Sr}_{\mathrm{x}} \mathrm{Co}_{0.50} \mathrm{Fe}_{0.50} \mathrm{O}_{3} ;(\mathrm{x}=0.1$ and 0.4$)$ Perovskite

Also, alkaline earth metals cations form ordered oxygen vacancies clusters in materials by acting like nucleating sites which can make them engaged for conduction. ${ }^{28,29}$ At a low value of temperatures, some extra energy is required for the dissociation of formed clusters for making the ions mobile. Therefore, the net activation energy of the material is the sum of dissociation as well as migration energy. On another side, the energy required at a high value of temperature is only for ions mobility inside the material and consequently, total activation energy is connected to migration energy which is always less than the value of activation energy at low temperature. ${ }^{30,3}$. The activation energy of the material has been obtained by the Arrhenius fit of electrical conductivity relating to temperature and shown in Fig.-9.
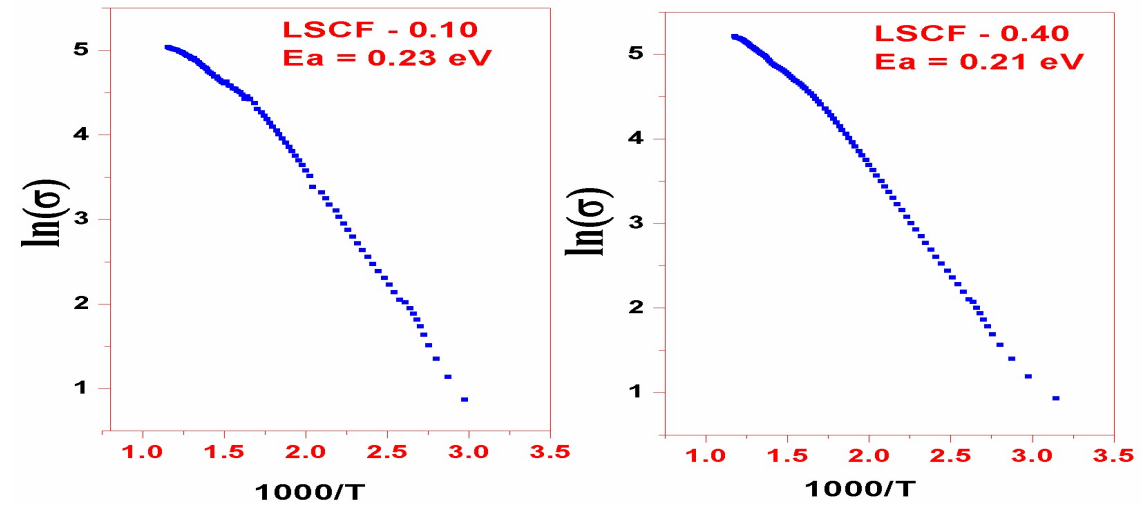

Fig.-9: Arrhenius Curves (ln $\sigma$ vs. 1000/T) of $\mathrm{La}_{1-\mathrm{x}} \mathrm{Sr}_{\mathrm{x}} \mathrm{Co}_{0.50} \mathrm{Fe}_{0.50} \mathrm{O}_{3}$ for $(\mathrm{x}=0.1$ and 0.4) Solid Solutions

Activation energy value calculated for $\mathrm{x}=0.10$ sample is $0.23 \mathrm{eV}$ and for $\mathrm{x}=0.40$ sample its value is 0.21 $\mathrm{eV}$ which also confirm that with $\mathrm{Sr}$ substitution, energy value decreases. The activation energy value of the material is established to be in superior agreement with the results of the obtained value of the conductivity.

\section{CONCLUSION}

$\mathrm{La}_{1-\mathrm{x}} \mathrm{Sr}_{\mathrm{x}} \mathrm{Co}_{0.50} \mathrm{Fe}_{0.50} \mathrm{O}_{3}\{0.10 \leq \mathrm{x} \leq 0.40\}$ perovskite ceramic material has been synthesized via solid-state method. The XRD confirms the cubic structure and single phase of the material. The obtained micrographs confirm that mean grain size constantly falls with rising $\mathrm{Sr}^{2+}$ substitution which in excellent agreement with the density value of the material. TGA graph shows the reduction of the material which causes the weight loss of the material. TEC value falls with $\mathrm{Sr}$ substitution and lies in the range (13.715.4) $\times 10^{-6}{ }^{\circ} \mathrm{C}^{-1}$ for $\mathrm{x}=0.10$ to 0.40 . The dielectric constant is large at low frequency and has a low value at 
RASĀYAN J. Chem.

Vol. 14 | No. 2 |1019-1027| April - June | 2021

high frequency. The impedance analysis established the non-Debye relaxation conduct of the samples. The electrical conductivities at unlike temperatures and frequencies have been increased with increasing $\mathrm{Sr}^{2+}$ content in the material.

\section{REFERENCES}

1. S.C.Singhal, Solid State Ionics, 135, 305 (2000), DOI:10.1016/S0167-2738(00)00452-5.

2. A. Hauch, S.H. Jensen, S. Ramousse and M. Mogensen, Journal of The Electrochemical Society, 153, A1741(2006), DOI:10.1149/1.2216562

3. R. Rivera-Tinoco, C. Mansilla and C. Bouallou, Energy Conversion and Management,,51, 2623 (2010), DOI:10.1016/j.enconman.2010.05.028

4. K. Chen and S.P. Jiang, Electrochemical Energy Reviews, 3,730(2020), DIO:10.1007/s41918-02000078-z

5. S.J.Skinner, International Journal of Inorganic Materials, 3(2), 113(2001), DOI:10.1016/S14666049(01)00004-6

6. H.H. Mobius, Journal of Solid State Electrochemistry, 2,16(1997), DOI:10.1007/s100080050018

7. S. Carter, A. Selcuk, R.J. Chater, J. Kajda, J.A. Kilner and B.C.H. Steele, Solid State Ionics, 53,597 (1992).

8. L. Gao, Q. Li, L. Sun, X. Zhang, L. Huo, H. Zhao and J.-C. Grenier, Journal of Power Sources, 371, 86(2017), DOI:10.1016/j.jpowsour.2017.10.036

9. W. Xia, Q. Li, L. Sun, X. Zhang, L. Huo and H. Zhao, Journal of Alloys and Compounds, 835, 155406 (2020), DOI:10.1016/j.jallcom.2020.155406

10. P. Plonczak, M. Gazda, B. Kuszand and P.Jasinski, Journal of Power Sources, 181,7(2008), DOI: $10.1016 /$ j.jpowsour.2007.12.019

11. J.M. Ralph, C. Rossignol and R.J. Kumar, The Electrochemical Society,150A,15 (2003), DOI: $10.1149 / 1.1617300$

12. S.P. Simner, J.F. Bonnett, N.L.Canfield, K.D. Meinhardt, V.L. Sprenkle and J.W. Stevenson Electrochemical and Solid-State Letters,5A,173 (2002),DOI:10.1149/1.1483156

13. S.P.Simner, J.F.Bonnett, N.L.Canfield, K.D.Meinhardt, J.P.Shelton, V.L.Sprenkle and J.W.Stevenson, Journal of Power Sources 113 (2003), DOI:10.1016/S0378-7753(02)00455-X

14. Y.Takeda, R. Kanno, M.Noda and O. Yamamoto, Bulletin of the Institute for Chemical Research,64,157(1986).

15. A. Weber and E. Ivers-Tiffee,Journal of Power Sources, 127,273(2004), DOI: 10.1016/j.jpowsour.2003.09.024

16. J. Richter, P.Holtappels, T.Graule and L. J.Gauckler Non-stoichiometry, Thermal Expansion and Electrical Properties of $\operatorname{Pr}_{1-\mathrm{x}} \mathrm{Sr}_{\mathrm{x}} \mathrm{Mn}_{1-\mathrm{y}} \mathrm{In}_{\mathrm{y}} \mathrm{O}_{3-\delta}$ Perovskites, Solid State Ionics, 179, 2284 (2008), DOI:10.1016/j.ssi.2008.08.007

17. F. Chen, O. T. Sorensen, G. Meng and D. Peng,Journal of Materials Chemistry, 7, 481 (1997), DOI: 10.1039/A605377G

18. D. Bahadur, W.Fischer and M.V. Rane, Materials Science and Engineering A, 252, 109(1998), DOI: 10.1016/S0921-5093(98)00653-4

19. K.S. Cole and H. Robert, Journal of Chemical Physics, 9, 341(1941), DOI:10.1063/1.1750906

20. M. Kumar and K. L. Yadav, Journal of Physics: Condensed Matter, 19, 202 (2002).

21. T. Badapanda, S. Sarangi, B. Behera and S. Anwar, Current Applied Physics,14,1192 (2014), DOI: 10.1016/j.cap.2014.06.007

22. U. Dash, S. Sahoo, P. Chaudhuri, S.K.S. Parashar and K. Parashar, Journal of Advanced Ceramics, 3,89 (2014), DOI: 10.1007/s40145-014-0098-9

23. B. Tiwari and R.N.P. Choudhary, IEEE Transactions on Dielectrics and Electrical Insulation, 5, 17 (2010).

24. B. Tiwari and R.N.P. Choudhary, Journal of Alloys and Compounds, 493, 1 (2010), DOI: $10.1016 / \mathrm{S} 0925-8388(10) 00343-9$

25. H. Singh, A. Kumar and K.L. Yadav, Materials Science and Engineering B., 176,540 (2011), DOI: $10.1016 /$ j.mseb.2011.01.010 
RASĀYAN J. Chem.

Vol. 14 | No. 2 |1019-1027| April - June | 2021

26. R. Ranjan, R. Kumar, B. Behera and R.N.P. Choudhary, Physica B.404, 3709(2009), DOI: 10.1016/j.physb.2009.06.113

27. M.R. Biswal, J. Nanda, N.C. Mishra, S. Anwar and A. Mishra, Advanced MaterialsLetters.5, 531(2014), DOI: 10.5185/amlett.2014.4566

28. I.Kosacki, H.U. Anderson, Y.Mizutani and K. Ukai, Solid State Ionics, 152, 431 (2002),DOI: $10.1016 / \mathrm{S} 0167-2738(02) 00382-\mathrm{X}$

29. K.Huang, R. S.Tichy and J. B. Goodenough, Journal of the American Ceramic Society,81,2565 (1998), DOI: $10.1111 / \mathrm{j} .1151-2916.1998 . t b 02662 . x$

30. J. H.Gong, Y.Li, Z. L. Tang, Y. S.Xie and Z. T. Zhang, Materials Chemistry and Physics, 76,212 (2002).

31. M.Kurumada, H. Hara, F.Munakata and E. Iguchi, Solid State Ionic,176, 245 (2005),DOI:10.1016/j.ssi.2004.08.010

[RJC-6153/2020] 